\title{
MODELS OF GOVERNANCE IN THE URBAN FUNCTIONAL AREAS: POLICY LESSONS FROM THE IMPLEMENTATION OF INTEGRATED TERRITORIAL INVESTMENTS (ITIs) IN POLAND
}

\author{
Tomasz KaczmareK ${ }^{1}$, Dagmara Kociuba ${ }^{2}$ \\ ${ }^{1}$ Institute of Socio-Economic Geography and Spatial Management, Adam Mickiewicz University in Poznań, \\ Poland \\ ${ }^{2}$ Department of Spatial Policy and Planning, Maria Curie-Skłodowska University in Lublin, Poland
}

Manuscript received: August 7, 2017

Revised version: September 29, 2017

\begin{abstract}
KaczmareK T., Kociuba D., 2017. Models of governance in the urban functional areas: Policy lessons from the implementation of integrated territorial investments (ITIs) in Poland. Quaestiones Geographicae 36(4), Bogucki Wydawnictwo Naukowe, Poznań, pp. 47-64, 1 table, 2 figs.

AвSTRACT: The aim of this paper is to present the genesis and the development of two models of the "leading path" to the integrated management of functional urban areas of voivodeship centres (FUA VC) in Poland in the context of the implementation of the new instrument of the EU's Cohesion Policy - Integrated Territorial Investments (ITIs). The implementation of ITIs is presented in the light of the inter-commune cooperation in FUA VC, which has been realised variously so far. As examples of the "leading path" to the integrated management based on the ITI, two functional areas have been selected, differing in this respect, Poznań in western Poland (an example of a bottom-up model) and Lublin in its eastern part (an example of a top-down model). In the conclusion, the instrument of ITI was evaluated as a factor which initiates, deepens or complicates the cooperation of local governments in FUAs. It has been emphasised, that in spite of the creation of organisational and financial instruments (ITIs) which activate the cooperation of self-governments in functional areas, one must take into account the need for legislative changes which give a special status to metropolitan areas, income sources and specific powers.
\end{abstract}

KEY wORDS: models of governance, functional urban areas (FUA), cohesion policy, Integrated Territorial Investments (ITIs), inter-municipal cooperation, path dependence, Poland

Corresponding author: Tomasz Kaczmarek, Institute of Socio-Economic Geography and Spatial Management, Adam Mickiewicz University in Poznań, ul. B. Krygowskiego 10,61-680 Poznań, Poland, e-mail: tomkac@amu.edu.pl

\section{Introduction}

Urban agglomerations, functional urban areas and metropolitan ones are the key drivers of growth with regard to production and services, labour market, innovation, technology, social and cultural life (Castells 2002). The harmonisation of development processes of a core city and its functional area leads to cooperative advantages and multiplier effects at a regional, national and international scale, which has been emphasised for many years in the literature (e.g. Hamilton 2000; Jouve, Lefevre 2002; Salet, Thornley, Kreukels 2003; Heinelt, Kübler 2005). The dynamic development of functional and spatial relations between a city and its surrounding, 
creates the factors not only for more active cooperation among municipal units, but also for the development of institutionalised, legal and organisational cooperation forms. Next to the factors favouring cooperation in functional areas, there are still limitations and barriers the elimination of which (by legal changes and an extension of financial support forms) can intensify the cooperation of local governments. Therefore, it is hardly surprising that in the recent years increasing attention in the programming of financial operations from the EU Structural Funds has been paid to the specific role of cities and their functional areas (in the case of large ones - metropolitan areas).

The goal of this article is to present a new instrument for the EU 2014-2020 Cohesion Policy, which is Integrated Territorial Investments (ITIs) and its implementation in functional urban areas of voivodeship centres (FUA VC) in Poland. The main objectives of the article are as follows:

1. Identification of rationales and problems of the integrated management of functional urban areas

2. Characteristics of ITI as a financial instrument for the support of the development of functional urban areas

3. Presentation of the principles of the ITI implementation in Poland

4. Analysis of functional urban areas in terms of the spatial range and institutional forms of the implementation of the ITI.

This paper presents various "leading paths" to the integrated management in functional urban areas based on the activities undertaken by local government units in the last years. Two functional areas were selected as examples: Poznań in western Poland and Lublin in its eastern part, differing in terms of the advancement of the management integration process. These are the examples of two models of the "leading path" to integrated management: top-down (Lublin) with the accent on external factors such as the support of the EU, government and local government and bottom-up (Poznań) with urban institutions cooperating with surrounding communes which have been developing for ten years. In the conclusion, the instrument of Integrated Territorial Investments was evaluated as a factor which initiates, deepens or complicates the cooperation of self-governments in functional urban areas.

\section{Rationales, objectives and forms of the integrated management of functional urban areas}

Functional urban areas, especially metropolitan ones, constitute compound administrative, settlement and socio-economic structures expressed by fuzzy boundaries. Therefore, there is a need for collective solutions of various problems connected with management and spatial planning. Most of them rest with public administration bodies, particularly local governments (Kaczmarek 2015). The problem with the management of functional urban areas results mainly from the mismatch between the territorial administrative organisation and dynamically changing socio-spatial structures and functional relations of core cities with their surroundings. Furthermore, in many EU states, the local government is relatively new, and the concept of functional urban areas is a new idea. This is particularly true in the case of former communist (Poland, Slovakia, the Czech Republic) and very centralised (the UK) countries. In some countries, several administrative reforms took place at once, invalidating the existing regions and creating three levels instead of two (e.g. Poland), or establishing a new unit of local government, namely metropolis (France). In other member states (e.g. Hungary), all sub-national governments have the same legal rank and standing. Thus, in practice, the management of functional areas of large cities is the greatest and most difficult of all the challenges facing the public policy and territorial management both in Poland and in Europe.

Working out an optimal solution so as to govern functional urban areas effectively has been the subject of ongoing debate across Europe for several decades (Herrschel, Newman 2002; Salet, Thornley, Kreukels 2003; Kaczmarek, Mikuła 2007; Priebs 2010; Heinelt, Razin, Zimmermann 2011). The process of the adaptation of existing management structures to executing public tasks and solving problems of functional areas develops differently in many European countries. Generally, there are two models of management integration in functional areas (Kaczmarek, Ryder 2015):

1. Introduction of institutionalised forms of the management of functional areas by the central 
government (metropolitan government) as the result of shifting local and regional competences to the metropolitan level ("top-down integration");

2. Integration of local government activities determined by bottom-up cooperative initiatives (metropolitan governance) and the determination of local units in their implementation ("bottom-up integration").

The process of management integration in functional urban areas is usually long-lasting, which is the result of many factors. Its initiators and promoters can be both, central government and local authorities which create bottom-up integrated activities themselves, especially if there are no government initiatives (Fig. 1). These activities are often parallel and the initiatives of the most active local governments involve lobbying for legislative and central regulations and seeking funds from support programmes. Supranational institutions such as the European Union with its own political and financial instruments also initiate policies concerning functional areas.

In both cases the reforms of functional areas management are not perfect and do not produce expected results. In the first one, top-down path towards the integrated management of functional areas is the result of the weakness of this process in local structures. The lack of consistent cooperative initiatives in the face of growing infrastructural, economic and social problems causes the creation of government initiatives intending to introduce top-down, most often obligatory, legal arrangements. Yet, excessive centralism in the management of functional urban areas can lead to their unsustainable development, taking place in isolation from the real citizens' needs and can generate increasing inequalities inside urban areas and adversely affect self-governing and the real influence of inhabitants on management (Sellers, Hoffmann-Martinot 2008). An attempt has been made to implement a top-down model at the European level taking into account the limitations and unsatisfactory results of the bottom-up model. It concerned especially metropolitan areas which, according to the EU, are going to be managed coherently so that their potential influence the growing competitiveness of countries and regions.

In the second case ("bottom-up") the cooperation of administrative units is perceived as an essential element of their effective functioning, both organisational and socio-economic. Nevertheless, local units are observed to be unwilling to undertake voluntary cooperation, due to the loss of some of their independence and the need to reach a consensus within so far autonomous local development policies (e.g. Jouve, Lefèvre 2002; Salet, Thornley, Kreukels 2003; Heinelt, Kübler 2005; Kaczmarek, Mikuła 2007). Cooperation has become a task of public administration in itself and although in the legislature of many countries it is optional, in practice it has become a norm and a necessity. The institution of inter-territorial cooperation is evaluated today as a sign of a flexible operation of the public administration system.



Fig. 1. Top-down and bottom-up activities for management integration in functional urban areas. Source: own study. 
According to Delcamp (1997: 91), "cooperation is an answer which a country, indirect structures or local communities themselves try to give to the inadequacy of institutions to economic and social realities". Bottom-up cooperation in functional urban areas (that does not exclude natural competitiveness, however) can lead to an advantage in terms of the rationalisation of management, coordination of investment location, more effective services, and what follows, an improvement in the quality of life and management (e.g. Salet, Thornley, Kreukels, 2003; Knieling 2011).

The management integration in metropolitan areas can adopt three basic forms:

1. The creation of another level of a territorial administration, by assigning to metropolitan areas a special status of a self-government unit or the establishment of an obligatory territorial corporation of a city with its surroundings in order to execute joint tasks,

2. A bottom-up formation of a metropolitan area of cooperation by optional municipal unions and agreements between units creating it,

3. The institution of informal or loosely established cooperation structures functioning as information or coordinating sources (councils, forums, conferences, consultative bodies etc.). In comparison to many European countries, whose management structure of functional urban areas and particularly metropolitan ones has already been well developed (e.g. Germany, France, the Netherlands, Italy), Poland is at the starting point of making important management entities out of functional areas (Porawski 2013). It has been influenced by historical factors (e.g. late entry into the suburbanisation phase), legal-administrative ones (a relatively short period of operation of local governments and creating possibilities to formalise the inter-municipal partnerships, as well as the effects of the administrative reform of 1999 replacing the old system of voivodeships with a new one, on which the existing FUA VC system is based) as well as political ones (a reluctant attitude towards the metropolis on the part of regional governments fearing loss of "influence" in such areas as well as the local authorities, especially in communes farthest away from the core city/cities). Undoubtedly, the need for the coordination of activities in functional urban areas is usually realised only with the appearance of negative developments and demographic (e.g. "the shrinkage of core cities") economic, transport and ecological problems.

\section{Cities and functional urban areas as subjects of the EU's territorial policy}

A new approach to cities and their functional areas in the EU's development policy should be considered in two aspects: 1/ the formation of an urban policy and 2/ the territorialisation of cohesion policy intervention. Both cases require working out standards in terms of integrated and multi-level governance in functional urban areas.

The introduction of a new paradigm of regional development at the beginning of the 21st century (OECD 2001) was connected with significant changes in the perception of the role of cities in the development of EU states. This process started already in the 1990s in the form of support for the development of cities from the European Regional Development Fund (ERDF), and particularly by the Urban Pilot Projects (1990-1993) and the Community initiatives URBAN and URBAN II (1994-2006) (www.ec.europa.eu). Their objectives are indicative of the European Commission's effort to create an urban policy at the European level, and of the main role of cooperation between countries, regions and cities in this process. An integrated approach to the development of cities and the need to involve the interested parties, including inhabitants were emphasised in these programmes. Promoted within the subsequent programme URBACT (2002-2020), it is creating contact networks between cities and sharing experience, which in practice facilitates peer learning, enhances city management skills and helps in the improvement of urban policies (www.urbact.eu).

A milestone in the formation of common objectives and principles of urban development at the EU level was the adoption of the Leipzig Charter on Sustainable European Cities (2007) in which the importance of an integrated approach to the development and management of cities was emphasised and the key role in the development of regions and their territorial cohesion was assigned to cities and their functional areas.

The experience of EU states show that the implementation of most of the tools intended to boost the development of countries and regions 
did not produce expected results, i.e. did not lead to a steady increase in the economic growth rate in the places of intervention (Rodríguez-Pose, Fratesi 2004; Gorzelak 2014). Thus, in the first decade of the 21st century, the activities aiming at the reorientation of the distribution policy of means from a one-size-fits-all to a place-based and territorial approach started to dominate. Competitiveness and economic cohesion built on the basis of specific territorial potential (territorial capital) of a given region were indicated as the new priorities of the EU policy (OECD 2001). These ideas, specified in F. Barca's report (2009), assume that the effectiveness of the intervention is related to the departure from the sectoral approach and support for the poorest countries/regions to the support of the endogenous potential of countries/regions by targeted interventions and multi-level governance so that they gain competitive advantages. This conception was reflected in the Lisbon Treaty, which came into force in 2009 and introduced a territorial dimension into the EU policy, and was implemented to the EU legislation in the 'Europe 2020' strategy (2010) and currently is being implemented within the Cohesion Policy in the 2014-2020 programming period.

It affected significantly the requirements concerning thematic concentration, targeted intervention and its adjustment to specific territory types encompassing many local government units (Markowski 2011; McCann, Ortega-Argilés 2013; Noworól 2014; Szlachta, Zaucha 2014). The introduction of new entities - functional urban areas (FUA) - to the development policy is going to serve the implementation of these assumptions. Their distinction results on one side, from the need for a territorial integration and, on the other side, from the territorialisation of intervention, which will eliminate negative effects of administrative borders and will result in greater effectiveness in functional urban areas. The establishment of the role of cities and their functional areas in the EU's regional policy and the introduction of the territorialisation of intervention principles were associated with the hope for an increase in management effectiveness. An attempt to implement the top-down model was undertaken taking into account the limitations and unsatisfactory effects of the bottom-up one. It concerned mainly metropolitan areas, which, according to the EU's policy rationales, should be governed coherently so that their potential would influence the competitiveness of countries and regions. Such territorial approach based on the governance principle was presented in the Leipzig Charter (2007) and also in the OECD expert assessments concerning urban policies in member states (e.g. OECD 2011). The experience of EU states showed that a placedbased approach and integrated development are implemented the most effectively by multi-level governance, Inter-Municipal Cooperation - IMC (Hulst, van Montfort 2007). In the FUA management, the main actors are public administration units from the central government to local authorities, non-governmental economic and social organisations and inhabitants working together in horizontal and vertical patterns (OECD 2009).

The Urban Agenda for the EU (Amsterdam Pact 2016) introduced significant changes within integrated urban management. The document indicates many new solutions, e.g. assumes decentralisation by delegating some of the powers concerning the programming and implementation of the EU's policy to local governments. It also strengthens the partnership and cooperation of local authorities with EU institutions, countries, business partners and social organisations in the creation of the urban policy involving the division into local, national and union levels.

The territorial dimension has become one of the main principles of programming in the European Union in the years 2014-2020. In this period, functional urban areas, which have been recognised rightful legal entities in politics, have become the beneficiaries of EU funds within a new cohesion policy tool - which is Integrated Territorial Investments (Principles... 2013).

\section{Functional urban areas as the subject of the territorial policy in Poland}

The inclusion of functional urban areas to the Polish development policy took place together with the adoption of the National Regional Development Strategy (NRDS) in 2010. It establishes strategic intervention areas (SIA) with the highest capacity to create economic growth and generate competitive advantages as the main recipients of a regional policy. These are mainly the largest cities from which development processes 
are supposed to spread (NRDS 2010: 73). A document which gave the geographical and planning dimension to SIA at the national level is National Spatial Development Concept (NSDC 2030) (2011). According to NSDC 2030, "urban functional areas as spatially continuous settlement system consisting of units separate in administrative terms. An urban functional area covers a compact urban area with a functionally linked urbanised zone. Those administrative areas may include urban communes, rural communes and urban-rural communes" (p. 187). Four basic types of FUAs have been distinguished based on their sizes ${ }^{1}$. It has been underlined at the same time that the functional areas of voivodeship centres play a key role in the socio-economic development of the country. These provisions were implemented into the Polish legal system in 2014 by the amendment of the Spatial Planning and Management Act $^{2}$ according to which functional urban areas include the city which is the seat of voivodeship authorities or a voivode and its closest, functionally linked surroundings (Article 2, Section 6b). The position of the cities and their functional areas in the Polish legal system has been consolidated with the adoption of the National Urban Policy in 2015 defined as "a targeted, territorially directed action of the country for the sustainable development of cities and their functional areas and the use of their potential in the country's development processes".

Despite introducing entities such as functional urban areas to the provisions of national development policies, the management of these areas was not a priority for the subsequent governments in Poland. In the case of Poland, a country with little experience in integrated territorial management and self-government cooperation, the recommendations included in the OECD overview of the National Urban Policy (2011) were of crucial importance for working out

\footnotetext{
These are: 1) the FUA of voivodeship centres (FUA of $\mathrm{VC}$ ), including metropolitan ones (metropolitan areas); 2) regional centres (FUA of RC), with the population between 100 and 300 thousand inhabitants; 3) subregional centres (FUA of SC) with the population between 50 and 100 thousand inhabitants; 4) local centres (FUA of LC) with the population below 50 thousand inhabitants, including some poviat cities (NSCD 2030: 181).

2 Spatial Planning and Management Act of 27 March 2003 (Journal of Laws No. 80, item 717, as amended).
}

management principles. It was emphasised that it was necessary to prepare a new generation reform of public multi-level governance and also to strengthen the cooperation of local government units, both vertical and horizontal.

In the last years, works on several draft bills introducing new forms of the cooperation of self-government units have been conducted, especially concerning functional areas of large cities. Their purpose was to achieve socio-economic and spatial cohesion and to create the basis for the effective and integrated management of metropolitan areas. An inner system of the metropolitan area was to resemble in general terms the rules of an inter-commune multi-task union. As stated in the White Paper of Metropolitan Areas (2013) "imposing the solution for the whole country by a top-down reform would not be an effective solution because it would be based on generalisations which might not reflect the real needs of Polish cities". Even the Metropolitan Union Act adopted by the Sejm on October 9, 2015 (commonly known as "the Metropolitan Act") did not come into force due to political changes. In return, the creation of "tailored legal solutions" for individual metropolitan unions was accepted. So far this solution has been applied in the Metropolitan Union in Śląskie Voivodeship, established on July 1, 20173 (Kociuba 2017a).

In the light of no political consensus regarding a legal regulation of the status of metropolitan areas, the last year's policy of the government was reduced to the financial support of bottom-up integration forms in functional urban areas. As stated in the White Book... (op. cit.) "A bottom-up management integration supported by financial incentives will start the solutions whose dynamics and direction will depend on the local authorities within metropolitan areas". In order to prepare functional urban areas (including metropolitan ones) to the absorption of EU funds, and most of all to promote and program their integrated development, the Ministry of Regional Development in 2012-2013 organised a special fund for them under the Operational Programme Technical Assistance (OP TA). It included grants

\footnotetext{
Under the Act of 9 March 2017 on the Metropolitan Union in Śląskie Voivodeship (Journal of Laws of April 6, 2017, item 730), repealing the Metropolitan Act.
} 
(awarded via a competition procedure) for the activities supporting local government units in terms of planning and the development of functional urban areas. The main concern that appears during the implementation of such competitions is related to the instrumentalisation of partnership and the creation of business cooperation dependent on specific projects and the possibility to obtain financial means in this regard (Janas, Jarczewski 2016). Several dozens of functional urban areas used the OP TA, including all metropolitan ones which have worked out various programme documents requiring cooperation and arrangements, such as development strategies (e.g. the metropolitan areas of Łódź and Warsaw) or the conceptions or studies of spatial development (e.g. the Poznan Metropolis, the Wrocław Functional Area). Regardless of their conditions-dependent nature, many of such studies have become the basis for the initiation of further, substantial and planned cooperation. Since 2015, the EU structural funds in the form of a new tool of Integrated Territorial Investments have become the main financial source of functional urban areas.

\section{Integrated Territorial Investments as an instrument for the integrated management of functional urban areas}

The strengthening of the mechanisms for the territorial coordination of intervention and management in functional areas in the current perspective manifests itself by the establishment of a new EU tool of the cohesion policy such as Integrated Territorial Investments (ITIs) under the Common Strategic Network. In a broader perspective, according to the European Parliament recommendations, the ITI implementation is going to strengthen the cooperation of different administrative units (EC 2014) $)^{4}$. Interestingly, not all countries use this tool (e.g. Austria, Denmark,

\footnotetext{
4 The ITI is an instrument which continues and develops the activities of Community states within integrated approach (Pietrzyk 2004) carried out in the 1970s and 1980s. It constitutes the legal response of the EC for the postulated in the recent years by member states need to strengthen an integrated approach to the programming of the development connecting policies, sectors and funds.
}

Sweden, Spain) and those using it, employ it in different areas (e.g. Kurowska, Lackowska 2016; Biniek et al. 2016). The natural areas of the ITI support are functional urban areas where, as has already been mentioned, development problems are often accompanied by the lack of inter-commune cooperation. The ITI instrument supports functional areas in such countries like Poland, the Czech Republic or Slovakia, whereas in Great Britain, Belgium or in Germany it is applied only in selected regions (England and Scotland, Brussels-Capital Region and Flanders, BadenWürttemberg and Schleswig-Holstein).

The legal basis for the ITI implementation at the EU level is established by three Resolutions of the European Parliament and the EU Council of December 17, 2013, i.e. no. 1303/2013 (Article 36), no. 1301/2013 (Article 7) and no. 1304/2013 (Article 12). In Poland, the determinants of the ITI implementation are included in the Partnership Agreement (2014), the provisions of which have been transferred to the national legal system in the so-called Implementation Act ${ }^{5}$. Thus, in the case of the ITI instrument, EU states and the regions governing operational programmes specify the EU top-down regulations (so-called double top-down regulations, see for more details: Krukowska, Lackowska 2016). Thus, local units (cities and communes situated in functional areas) are the ITI receivers, in this case we are dealing with territorial governance.

The ITI is supposed to encourage the development of urban territories and their functional areas by promoting the cooperation of their constitutive administrative units, the implementation of common inter-sectoral, integrated projects meeting comprehensively the needs and problems of a given functional area whose range exceeds administrative borders and covers neighbouring units. The support for these areas is to be programmed by an integrated, inter-sectoral territorial strategy - the ITI Strategy (an ex-ante condition to the ITI activation) or other strategies or territorial pacts. The actions indicated in the strategy are implemented in the form of project bundles financed from several priority axes and

\footnotetext{
Act of July 11, 2014 on the principles of the implementation of cohesion policy programmes funded in the financial perspective 2014-2020 (Journal of Laws 2014, item 1146, as amended).
} 
operational programmes; one project can be jointly financed from various funds (ERDF, ESF and the Cohesion Fund). Formalised partnerships for local government units - the ITI unions having little power over the task delegation within the Regional Operational Programmes (ROP) allocation management - are responsible for the ITI implementation. The establishment of a non-institutionalised partnership form, so-called the ITI Union, has become a sine qua non condition for the ITI implementation by local governments. Inter-commune or commune-poviat municipal unions, associations and agreements of local government units have become the legal forms of the partnership. According the national guidelines (Principles... 2013), ITIs are obligatory implemented in the FUA of voivodeship centres and in accordance with the decision of voivodeship authorities - in regional and sub-regional centres. The ITI adaptation in the 17 largest Polish functional areas formed around cities - the capitals of voivodeships - is presented below.

\section{Implementation of Integrated Territorial Investments and the present forms of cooperation in functional urban areas}

Since 1990, self-government legislation in Poland has provided the legal basis for inter-commune cooperation and since 2015, for commune-poviat cooperation, and enables local governments to make autonomous decisions regarding this case. Since approximately ten years, we have been observing the bottom-up process of building local coalitions of cities and the communes and poviats surrounding them, which can be defined as the beginnings of the integration management process and planning in functional urban areas. Various less formal structures (councils, partnership agreements) appeared especially in the influence zones of large cities (metropolises) and more formal (companies with the participation of local governments, municipal unions, associations) for the purpose of solving common problems and coordinating management in metropolitan areas. The following are the most advanced ones (the foundation year in brackets): the Association of the Szczecin Metropolitan Area (2005), the Upper
Silesian Metropolitan Union "Silesia" (2007) and the Poznań Metropolis Association (2011, the former Poznań Agglomeration Council, 2007). In the last two cases, the basis for cooperation in the form of a development strategy, which has been implemented for several years (Silesia since 2010, the Poznań Metropolis since 2011), was even created. In most of the functional areas, however, cooperation was less advanced or less institutionalised (e.g. Opole, Białystok, Łódź, Lublin). In some functional areas there was strong competition for many years and their main cities adopted antagonistic attitudes to one another (GdańskGdynia and Bydgoszcz-Toruń) or as in the case of Warsaw and Rzeszów - a core city and neighbouring communes. Taking into account the previous forms of cooperation and the ITI implementation, Kurowska and Lackowska (2016) divided functional areas of voivodeship cities into four categories:

1. Late pioneers (Lublin, Zielona Góra, Gorzów Wlkp. Opole, Łódź, Bydgoszcz-Toruń): due to the fact that there was no previous cooperation, the ITI instrument provided an incentive to establish and intensify it.

2. Restorers (Warsaw, Białystok, Wrocław): the ITI was a catalyst for cooperation, which was previously less effective despite various attempts to institutionalise it, or was limited only to a narrow field.

3. Competitors (Silesia, Olsztyn, Rzeszów, Kielce): established ITI unions were parallel to the existing cooperation forms, and act separately based on their abilities to participate in investments financed under ITI funds.

4. Successors (Poznań, Szczecin, Gdańsk-Gdynia), ITI unions were established based on the existing cooperation forms by adopting their range and legal formula (Poznań and Szczecin) or the combination of two existing cooperation areas (Gdańsk and Gdynia).

It follows from the above that the ITI instrument implementation in Poland has encountered a diverse situation in terms of the cooperation of the largest cities with their surroundings. It is worth noticing that in accordance with adopted national principles, ministerial criteria were to decide on the delimitation of ITI unions and the final confirmation of the ITI union borders was assigned to voivodeship authorities. Moreover, the ITI strategy could not have been presented 
Table 1. Size of functional urban areas by the MRD delimitation and in the practice of the ITI implementation.

\begin{tabular}{|c|c|c|c|c|c|c|}
\hline \multirow{2}{*}{ Name of FUA } & \multicolumn{2}{|c|}{ Number of municipalities } & \multicolumn{2}{|c|}{ Area in thous. $\mathrm{km}^{2}$} & \multirow{2}{*}{$\begin{array}{c}\text { Differences } \\
\text { in the number of } \\
\text { municipalities }\end{array}$} & \multirow{2}{*}{$\begin{array}{l}\text { Legal form } \\
\text { of FUA }\end{array}$} \\
\hline & By MRD & In practice & By MRD & In practice & & \\
\hline $\begin{array}{l}\text { Miejski Obszar Funkcjonalny } \\
\text { Subregionu Centralnego }\end{array}$ & 46 & 73 & 3.0 & 5.6 & +27 & As \\
\hline $\begin{array}{l}\text { Bydgosko-Toruński Obszar Funk- } \\
\text { cjonalny }\end{array}$ & 19 & 23 & 3.2 & 3.7 & +1 & A \\
\hline $\begin{array}{l}\text { Miejski Obszar Funkcjonalny } \\
\text { Poznania }\end{array}$ & 21 & 22 & 2.5 & 3.1 & $\begin{array}{l}+4 \\
-3\end{array}$ & As \\
\hline $\begin{array}{l}\text { Miejski Obszar Funkcjonalny } \\
\text { Trójmiasta }\end{array}$ & 19 & 30 & 2.0 & 3.0 & +11 & As \\
\hline Warszawski Obszar Funkcjonalny & 50 & 40 & 3.8 & 2.9 & -10 & A \\
\hline $\begin{array}{l}\text { Szczeciński Obszar Metropoli- } \\
\text { talny }\end{array}$ & 9 & 13 & 1.9 & 2.8 & +4 & As \\
\hline Łódzki Obszar Metropolitalny & 19 & 28 & 1.8 & 2.5 & +9 & As \\
\hline $\begin{array}{l}\text { Miejski Obszar Funkcjonalny } \\
\text { Aglomeracji Opolskiej }\end{array}$ & 12 & 21 & 1.4 & 2.4 & +9 & As \\
\hline Wrocławski Obszar Funkcjonalny & 15 & 15 & 2.4 & 2.3 & - & A \\
\hline Białostocki Obszar Funkcjonalny & 9 & 10 & 1.6 & 1.7 & +1 & As \\
\hline Lubelski Obszar Funkcjonalny & 15 & 16 & 1.5 & 1.6 & +1 & A \\
\hline $\begin{array}{l}\text { Miejski Obszar Funkcjonalny } \\
\text { Olsztyna }\end{array}$ & 7 & 7 & 1.4 & 1.5 & - & A \\
\hline Kielecki Obszar Funkcjonalny & 10 & 12 & 1.1 & 1.3 & +2 & A \\
\hline Krakowski Obszar Funkcjonalny & 23 & 15 & 2.0 & 1.3 & $-9 /+1$ & As \\
\hline Rzeszowski Obszar Funkcjonalny & 14 & 13 & 1.2 & 1.0 & -1 & As \\
\hline Miejski Obszar Funkcjonalny ZG & 6 & 5 & 1.0 & 1.0 & $-1^{6}$ & A \\
\hline Miejski Obszar Funkcjonalny GW & 5 & 5 & 0.8 & 0.8 & - & A \\
\hline Total & 299 & 348 & 32.6 & 38.5 & - & - \\
\hline
\end{tabular}

As - association, A - agreement

Source: own study.

in the existing strategic documents, which had to be replaced by new, separate ones. Local governments also had to sign the agreement of the ITI implementation with the voivodeship board in order to make it possible to transfer financial means for the ITI implementation from the Regional Operational Programme.

Thus, the decision on the ITI implementation in Poland required on the one hand, the delimitation of the FUA range and, on the other hand, the formation of ITI unions. In practice, the most controversial was the establishment of the borders of core supporting areas (Śleszyński 2013, 2014; Heffner, Gibas 2013; Herbst, Wójcik 2013), which involved the creation of partnerships and their formalisation (Kaczmarek 2015; Frankowski, Szmytkowska 2015; Kurowska, Lackowska 2016; Kociuba 2017).

The creation of formal foundations for the delimitation of the FUA of voivodeship centres was assigned to the Ministry of Regional Development (MRD), responsible for the
ITI implementation. As a result, a document Delimitation criteria of functional urban areas of voivodeship centres was drawn up $^{7}$, which was passed to voivodeship self-governments by the MRD in February 2013 and became the basis for the determination of the "voivodeship ITI" implementation area (Śleszyński 2013). One of the most important tips for local governments preparing for the ITI implementation (confirmed by the provisions of the Partnership Agreement) was that the "voivodeship ITI" must include a voivodeship capital, all core cities of a functional

6 After the incorporation of Zielona Góra commune within the Zielona Góra City on January 1, 2015, the number of municipalities in the ITI Union was reduced to 5. The area of ITI implementation remained unchanged.

In the document, 18 FUAs of voivodeship capitals were appointed (including the list of communes), however, the ITI implementation area in Kujawsko-Pomorskie Voivodeship concerned one compact two-core (cities Bydgoszcz and Toruń) functional area. 
area and other communes of this area - jointly at least half of the communes determined by the Delimitation criteria... (PA 2014: 211). For most local governments, this provision has become the basis for the introduction of changes in spatial ranges of cooperation (Table 1). The final coverage of FUAs is shown in Fig 2.

The delimitation of functional urban areas for the ITI implementation needs was performed on several levels, which confirms that this instrument should be included in the multi-level governance category. Basically, there were three decision levels to decide the spatial range of an ITI union (Kociuba 2017a):
1. Ministerial. Voivodeship governments adopted in full or with some minor changes $(+/-$ one commune) the guidelines indicated in the Delimitation criteria... (2013). This alternative was chosen by peripheral and the least populated FUAs of eastern Poland (Rzeszów, Lublin, Białystok, Olsztyn) and the FUAs of Lubuskie voivodeship (Gorzów, Zielona Góra). It is worth emphasising that the above-mentioned ITI unions were established mostly in less formal agreements.

2. Regional. The basis for the selection of the ITI support area was the delimitation carried out in voivodeship documents (strategy, spa-



Fig. 2. Range of ITI unions in functional urban areas (source: own study based on the ITI strategies of voivodeship centres).

Source: own study. 
tial development plan: Łódź, Katowice) or in special expert assessments commissioned at the regional level (Bydgoszcz-Torun, Kielce). Apart from hard - statistical ministerial criteria, voivodeship documents usually also accommodated the criteria of existing cooperation among communes or their declarations to become part of an ITI union.

3. Local. The delimitation was carried out based on the present cooperation range, within an already existing association (Poznań, Szczecin) or two associations (Tri-City). The agreements of communes (Warsaw) or associations especially formed for that purpose (Cracow, Opole) were also characterised by bottom-up delimitations.

The analysis of the conducted delimitations of functional urban areas for the needs of the ITI instrument implementation (Kociuba 2017a) shows that only in four cases ministerial guidelines were adopted in full and in ten cases their territorial range was extended, especially in the Katowice functional urban area. His area (the ITI of the sub-region of central Śląskie Voivodeship) was extended by 27 communes in the comparison with the reference delimitation of the ministry. In three ITI strategies of voivodeship centres the delimitation recommended by the ministry was narrowed down. According to Janas and Jarczewski (2016), the extension of the cooperation range and inclusion of the majority of potential beneficiaries, even from peripheral areas could have been motivated by the acquisition of higher funds from the ITI instrument (calculated in proportion to the number of inhabitants). The reduction of the borders of some functional urban areas could have been related to local political antagonisms and resulted in the unwillingness to start cooperation. In the case of Bydgoszcz and Torun, the obligatory model of bipolar cooperation was adopted (in accordance with the NSDC 2030) despite little experience so far and undeveloped cooperation forms of both cities. A functional urban area of Poznań - a centre with significant achievements in self-government cooperation within Poznań agglomeration (discussed later in the article) - is quite exceptional at the national scale. As a result, the Wielkopolskie Voivodeship Board established the borders of the Poznań functional urban area, which were implementing the ITI strategy, based on the existing activity range of the Poznań Metropolis Association, and not on the delimitation executed by the Wielkopolska Spatial Planning Office (the range of the FUA was almost twice as big there).

As has already been mentioned, to implement the ITI instrument, local governments were obliged to establish an institution in the form of a municipal union, an association or an inter-commune agreement. Out of the 17 functional urban areas included in the research, eight adopted an inter-commune agreement and nine became associations (Table 1). No analysed functional urban area operates in the formula of a multi-task municipal union. It is the evidence of a great distance of local governments to the greater institutionalisation of territorial cooperation (Kociuba 2017).

As Krukowska and Lackowska (2016: 96) notice, a top-down initiative of cooperation did not contribute much to any form of closer cooperation. A top-down cooperation order "did not encounter strong resistance, yet it did not change the way people think about cooperation at the metropolitan scale". Relatively frequent criticism of the ITI strategy is also indicative of that. Critics draw attention to the tendency of recording numerous, but not interrelated projects of the local scale of influence in this document, which opposes the ITI concept (Kozak 2015). Janas and Jarczewski (2016: 22) are even more critical, stating that "most local intergovernmental partnerships in Poland operating in functional urban areas were formed on the principle that projects create partnerships. However, it should be the other way around - partnerships should activate projects". In the case of ITI unions, one can distinguish partnerships operating for many years and established for strategic objectives (cooperation model) and those not created on the basis of the previous experience of long-term cooperation where the absorption of the EU funds has become a main incentive for cooperation (interim model) (Kociuba 2017). Two cases, relevant to this division, are analysed in the subsequent chapter.

\section{Implementation paths of Integration Territorial Investments: an example of functional areas of Poznań and Lublin}

In the literature on the territorial partnership the dependence of durability and the effectiveness of self-government cooperation of 
their previous experience is often emphasised (Heinelt, Kübler 2005; Kaczmarek, Mikuła 2007; Heinelt, Razin, Zimmermann 2011). The success of the ITI instrument implementation should be attributed not only to its financial impact, but also to the tradition of cooperation and the development of long-term cooperation forms. As noticed in the analysis of the dependence of ITI structures (a range and legal formula) on previously existing cooperation forms, top-down adaptation pressure played a less significant role in the case of the cooperation tradition. Then, the conception of "path-dependency" is clearly indicated, upon which a variety of decisions and development directions are the result of "historical institutionalism", i.e. former events and decisions (Kurowska, Lackowska 2016). Thus, it is worth noting that for some functional areas the ITI instrument has become an incentive to create formal structures and cooperation programmes. But then, for the local governments which have already been on the defined integration path of governance, ITIs have become only additional elements, basically strengthening their cooperation in programming and finances.

Taking into consideration the factors that are catalysts of actions of local governments, one can distinguish at least two "paths" leading to more advanced management forms in functional areas. The first path ("from the top") presents the establishment of cooperation in accordance with the top-down procedure by the necessity to redefine the ITI territorial union: its area (delimitation), organisation (legal form) and programme (strategy). A model integration path of the "bottom-up" management seems to be more durable and effective. Here, in the face of new development problems, the cooperation aiming at their solution starts much earlier before the ITI instrument appears. In these functional areas in which local government units have cooperated for years, the adaptation process to the EU's new territorial policy is generally easier. It is possible to achieve a consensus faster while establishing common projects within the ITI strategy whose principles can be based on previous programming documents, and also to develop a joint approach to the borders of functional urban areas where the ITI strategy will be implemented. Two functional areas were selected as examples of various paths leading to the integrated governance in functional urban areas: Poznań in western Poland and Lublin in its eastern part, with a different level of inter-commune cooperation.

\section{Lublin Functional Area - the agreement of communes}

The Lublin Functional Area is an example of the top-down model of achieving cooperation. It was institutionally established in the weakest possible cooperation form, i.e. inter-commune agreement, only after the ITI instrument appeared. It is worth emphasising that in this case the intermediary institution of the ITI implementation is a core city responsible for, e.g. the development of a strategy and the selection of the projects for implementation (the ITI Office operates within the Lublin City Office structures). A solution in which one of the partners functions as an intermediary, can generate potential conflicts and may lead to the situation where a stronger party will use its advantage at the subsequent stages of the ITI implementation. The lack of formal cooperation so far in strictly defined territorial borders caused the range of the Lublin Functional Area (LFA) to be top-down delimited by the voivodeship self-government guidelines based on ministerial criteria (The ITI strategy for the Lublin Functional Area 2016). There was one departure from the delimitation by the Ministry of Regional Development, i.e. the urban-rural commune of Nałęczów was included due to its transport connections and the fact that it functions as a health resort. The Lublin Functional Area consists of 16 communes situated in five poviats. It occupies the area of $1,582 \mathrm{~km}^{2}$ and has the population of 544.1 thousand ( $25 \%$ of the Lubelskie Voivodeship population), over $60 \%$ of whom live in Lublin. In the functional and spatial structure of the area, Lublin and Świdnik are the strongest.

The territorial self-governments of the Lublin Functional Area do not have much experience in inter-commune cooperation and the implementation of common projects or strategic activities. The successful cooperation between the communes of Lublin and Lubartów in municipal waste management has been the longest one, since 1991. The Partnership Agreement on the Lublin Metropolitan Area (LMA), concluded by 
the Marshall of Lubelskie Voivodeship in 2005, a "top-down" agreement, gave hope for the development of wider inter-commune cooperation under the development policy. It included Lublin and 44 communes situated in the poviats of Lubartów, Lublin, Łęczna and Świdnik. As a result of the implementation of the provisions of the agreement, the Urbanisation Study of the Lublin Metropolitan Area (2009) was developed. Its conceptual solutions and provisions were supposed to be the guidelines in the development of the spatial policy of the LMA. It was not the case, however. The Partnership Agreement did not result in other common projects, and a "top-bottom" form was not well received by local governments. At present, the adopted form of the ITI cooperation involves only $36 \%$ of communes, the signatories of the above-mentioned agreement. More successful attempts at inter-commune cooperation were connected with the EU spending in the 2007-2013 perspective. The most important include the extension of the Świdnik airport, the construction projects of five roads and the modernisation of four railway lines. The development of the functional solutions for public transport was an important, but only a sectoral cooperation form, initiated by the city of Lublin. In 2013, the Lublin City Council adopted "The plan for the sustainable development of public transport for Lublin commune and the neighbouring communes". The implementation of the project influenced an increased use of public transport, especially by the inhabitants of the communes adjacent to Lublin. In 2008, 41 communes (Lublin and the communes of the poviats of Łęczna, Świdnik, Lubartów and Lublin) signed the Partnership Agreement establishing the Lublin Metropolitan Area (LMA) as an inter-commune cooperation platform targeted at attracting national and foreign investors and the development of the investment marketing of the region. The establishment of the Economic and Business Forum LUB-INVEST in 2009 - one of the most important regular events inviting national and foreign investors to this day - is the greatest value added of the project.

The implementation of these projects contributed to a lesser or greater extent to the development of the cooperation mechanisms of local government units. It is worth noticing that the implemented projects varied in the number of participants (from 2 to 173), the range (from local to sub-regional), importance (the construction of such key investments as an airport, ring road, metropolitan train) and objectives (from public transport solutions to economic marketing).

Summing up the integration activities in the Lublin Functional Area, one should pay attention to four issues:

1. Most of them were infrastructural projects;

2. The effects show that in terms of cooperation most of them were successful in creating products improving transport, the quality of inhabitants' life as well as the image of the region in the eyes of tourists and investors;

3. The position of a leader was strengthened institutions with their seats in Lublin were the beneficiaries of most projects;

4. Most actions did not take place under an agreement or contract - communes were connected by the possibility of receiving funds and not by the "bottom-up" inter-commune cooperation.

It was only the possibility to use $5 \%$ of the Regional Operational Programme in ITI that changed it. The formalisation of the partnership within the ITI union in the case of LFA proceeded in two stages. On May 13, 2014, the Cooperation Agreement of the Local Government Units for the Lublin Functional Area was signed. On its basis the leader of LFA - the city of Lublin - was elected, the most important trends in the LFA development were established, the ITI Programme Council was appointed, the decisions regarding the prepared ITI Strategy (finally approved on March 9, 2016) ${ }^{8}$, and also the proposed projects within the ITI LFA were evaluated. The final formalisation of the partnership took place on March 30, 2015 by signing the Commune Agreement of the Lublin Functional Area on the cooperation in the implementation of the ITIs in the EU 20142020 financial perspective.

In the ITI strategy development, the implementation of the project "Support for the ITI in the Lublin Functional Area" financed within the already mentioned OP TA. The project, whose beneficiary was the commune of Lublin, included a series of training courses and workshops. A number of audits and analyses were commissioned, e.g. of the existing studies of spatial management conditions of the LFA communes. All these activities contributed to the development of the Strategy for the Integrated Territorial Investments of the Lublin Functional Area in the years 2014-2020 (2016). 
The cooperation of the LFA communes, established temporarily in order to spend the EU funds, is a typical example of the implementation of the "top-down" model, in which the entire responsibility for the ITI implementation and management is transferred to a leader - a core city. The present activities have little to do with the management integration in a functional urban area, and the ITI implementation in the LFA communes is considered as "a necessary evil", not as an element strengthening the inter-commune cooperation.

\section{Poznań Functional Urban Area - the Poznan Metropolis Association}

In the Poznan functional urban area the foundations for coherent management have been continuously built for ten years. It includes the establishment of organisational self-government ties in the political, economic and social areas, defined more often as metropolitan integration. The partners in this process are the city and poviat of Poznan, cities and communes interested in metropolitan cooperation and, to a lesser extent, the voivodeship government and economic, social and scientific institutions. On May 15, 2007, the President of Poznan, the Head of Poznań poviat (starosta), and heads of rural commune governments and mayors of 17 communes of Poznań poviat signed the "Agreement on cooperation among the Poznań agglomeration self-governments". Its participants formed the Poznan Agglomeration Council, which operated for three years as a forum for information exchange between local government units and the establishment of fields of cooperation, taking various legal forms in the future. On April 29, 2011, the Poznań Metropolis Association was registered 9 . The city and poviat of Poznań became

The authorities of the Association are: the General Meeting called the Metropolis Council, the Board and Auditing Committee. The Metropolis Council is a decisive and controlling body of the Association consisting of heads of self-government units (mayors, president, heads of poviat) who belong to the Association as their representatives. According to the Articles of Association, the President of Poznan is the President of the Board. The Association executes its tasks with the help of the Association Office with the Director. its members. The main task of the Association is to coordinate inter-commune cooperation and to implement the common Poznań Metropolis 2020 development strategy. The Association is a legal entity and is established for an indefinite period. The Poznań Metropolis Association laid down several documents important for the integration of its functional area, e.g. the Plan for a low-Emission Economy for the Poznan Metropolis (2015), the Master Plan for Poznan Metropolitan Railway (2016) or the Conception of Spatial Development Trends for the Poznan Metropolis - an integrated approach (2015). The Metropolitan Planning Commission, appointed in 2017 by the Association members, is responsible for the implementation of the Conception mentioned above.

Executive tasks and powers consisting in the organisation and provision of public services in the functional area are implemented by single-task entities - purpose-oriented associations, commercial companies controlled by local governments and sectoral associations, or by selected local government units via agreements. These are, e.g. the purpose-oriented union Poznan Agglomeration Waste Management, Aquanet S.A. (a water and sewer company) and the Poznań Local Tourist Organisation. Agreements between the city and poviat of Poznan concerning, e.g. public safety (police, fire department), labour market, social welfare and education are important elements of integrated management in the functional area. The city and agglomeration communes signed the agreements in the area of education and the public transport organisation. In the latter case, the prices are integrated by the introduction of the Poznan Electronic Agglomeration Card (PEKA).

In terms of local government cooperation with the economic sector, the Entrepreneurship and the Employment Support Network has been operating since 2002 in the Poznan Metropolis. Since 2008 local governments and the Chamber of Industry and Commerce of the Wielkopolska Region have organised the Poznan Metropolis Economic Forum on an annual basis. The Labour Market Observatory of the Poznan Agglomeration, which monitors and forecasts labour market needs, has been operating since 2013. In the Poznan Metropolis the cooperation between local governments and the scientific 
milieu has been developing well. Academic experts support management, spatial and strategic planning in the agglomeration with knowledge and innovative ideas. In 2009, the members of the Poznan Agglomeration Council unanimously voted for the financial support of the research project "Functioning and the development trends in the Poznan Agglomeration", implemented by the Metropolitan Research Centre (CBM) at Adam Mickiewicz University. The project resulted in the development of the Poznań Metropolis Development Strategy 2020 (2010) and the Study of Spatial Development of the Poznan Agglomeration (2012). Since 2009 the Metropolitan Research Centre has been publishing a scientific series, The Poznan Agglomeration Library, whose 30 numbers were dedicated to the most important development problems of this area.

The different forms of cooperation and management integration presented above contributed to the fact that the Poznan Metropolis Association, which is a legal personality, assumed the role of an intermediary institution in the ITI. On September 18, 2013, the Metropolis Council as the decisive body of the Association adopted resolution no. 3/2013 according to which the Association "assumes the tasks of the ITI Union". The area of the ITI implementation in Wielkopolskie Voivodeship was defined with resolution no. 4013/2013 of the Board of Wielkopolskie Voivodeship as of November 7, 2013. The Poznań Metropolis Council adopted resolution no. 6/2015 of November 6, 2015 concerning the ITI strategy.

The Poznań Functional Urban Area comprises 22 communes which are the members of the Poznań Metropolis Association. The Association includes the poviat of Poznan where 17 out of 22 member communes are situated. As at 2015 the Poznań FUA covers an area of $3,082 \mathrm{~km}^{2}$ with a population of $1,022,844$, the density of which is 332 inhabitants per $\mathrm{km}^{2}$, almost three times higher than the average in Poland. The Metropolis area covers $10.3 \%$ of Wielkopolskie Voivodeship and accounts for $29.4 \%$ of its population. According to the Central Statistical Office, the FUA employment constitutes $41.0 \%$ in Wielkopolskie Voivodeship.

To sum up the way to the ITI instrument implementation by the Poznan Metropolis
Association, the most important elements conducive to this process are:

1. Since the country's administrative reform in 1999 and the restitutions of poviats the management integration between the city and poviat in the Poznan Functional Area has taken place, which builds a "milieu of trust" for the cooperation development between local governments;

2. Since 2007 (the appointment of the Poznan Agglomeration Council) the cooperation between Poznań and neighbouring communes has strengthened and resulted in greater institutionalisation in the form of establishing the Poznań Metropolis Association, an ITI beneficiary since 2013;

3. Before starting the work on the ITI strategy, the Poznan Functional Area, as one of the few in Poland, had already had its own document determining the development trends in the long term. The Poznan Agglomeration Development Strategy has become the basis for the ITI Strategy of the Poznan Functional Urban Area, the Poznań Metropolis 2020. Not only did it accelerate the development of the document, but it was also conducive to reaching a consensus on strategic programmes.

4. The ITI Union of the Poznan FUA, as one of the few in the country, has been approved in the borders of the Poznan Metropolis Association existing so far and has not been changed by ministerial criteria or voivodeship delimitation.

In the Report on the state of the Polish cities (Janas, Jarczewski 2016), the Poznań Metropolis was described as the national leader of integrated management in functional urban areas. In the light of the path-dependence conception, the implementation of the ITI instrument is based on former experience and the social capital of the members of the Poznan Metropolis Association. It is hard to predict whether the ITI implementation will contribute to closer cooperation in the Poznań Functional Area, whether it will bring about a multiplier effect in other areas of metropolitan integration or, on the contrary, whether it will cause the phenomenon of being "stuck on a path", and the engagement in the implementation of ITI programmes will delay the realisation of potential new projects. 


\section{Conclusions and recommendations}

The management of functional urban areas, especially metropolitan ones, has been discussed in Poland for almost 10 years. Although the subject was emphasised in the most important national documents (National Spatial Development Concept 2030, National Strategy of Regional Development 2020), it was not of high priority for the central authorities for many years. As a result, the reform regulating the administrative system of urban regions has been abandoned. At the same time, bottom-up cooperation in the Polish functional areas is still at an early stage of development and it cannot always be reduced to integrated management forms, adjusted to a given area and the scale of local problems.

Therefore, the programme support of the European Union is becoming increasingly important for integrated management in functional areas. A new approach in the EU's territorial policy is accompanied by the appearance of the ITI instrument, which supports integrated management in functional areas, mainly voivodeship centres in the country. Thus, cities and communes, which had to create partnership territorial unions and develop the strategies of the use of the EU support funds in order to become their beneficiaries, joined the group of functional areas with the advanced cooperation forms. Will financial support within the ITI programme, dedicated to functional urban areas in the 2014-2020 perspective, become a catalyst for integrated management in metropolitan areas? Will the top-down cooperation "for money" produce measurable economic and social effects? These questions can only be answered in a few years' time.

It is already at the stage of the implementation of the ITI instrument, both in the "bottom-up" and the "top-down" model, that its potential benefits can be indicated, and these are:

1. The beginnings of the decentralisation of the urban policy to a local level (only local governments, whose representatives can become the managing authority, decide about the ITI projects and the allocation of funds);

2. The mobilisation of local governments, creation of common strategies and development programmes crucial for obtaining financial support;
3. The revival of previously dissolved or neglected local government partnerships and the creation of new ones;

4. The creation of new leaders, who initiated and promote inter-commune cooperation;

5. A chance for the more integrated functional and spatial development of functional areas of large cities.

The success and long-term effect of the implementation of ITI strategies depend largely on local factors, such as the determination of local governments, effective management, creation of the conditions for the multiplier effects of joint projects as well as social acceptance and support for strategic programmes. Despite the creation of the organisational and financial ITI instruments activating the cooperation of local governments in functional areas, one must take into account the need for legislative changes which give them (especially metropolitan areas) a special status, specific powers and provides the source of income. The change in the local government and planning law, however, is still extremely difficult, and the relevant legislative proposals are met with the strong resistance of various advocacy groups (including local governments themselves). According to the authors of the OECD Report The National Urban Policy Review of Poland (2011), even in the case of successful common "bottom-up" activities in metropolitan areas, it is still necessary to work out the legal platforms of inter-commune cooperation, allowing cities, communes and poviats to engage in the joint settlement of social, economic and spatial development problems. In this context, a possible range of the metropolitan reform in Poland should be considered. Izdebski postulates (2010) that this reform could be adopted in stages and should be flexible in terms of system and territorial solutions for particular metropolitan areas in the country.

\section{References}

Barca F., 2009. An Agenda for a Reformed Cohesion Policy, A place-based approach to meeting European Union challenges and expectation. Independent Report for DG Regio, European Comission, Brussels.

Binek J., Opravil Z., Chmelar R., Svobodova H., 2016. Cooperation and mutual relationships of cities and their hinterlands with regard to the operation of EU integrated development instruments. Quaestiones Geographicae 35(2): 59-70. 
Castells M., 2002. Local and global: Cities in the network society. Tijdschrift voor Economische en Sociale Geografie 93: 548-558.

Delimitation criteria of functional urban areas of voivodeship centres (Kryteria delimitacji miejskich obszarów funkcjonalnych ośrodków wojewódzkich), 2013. Ministry of Regional Development, Warsaw.

Delcamp A., 1997. La cooperation intercomunale en Europe. In: L'intercomunalite - balance et perspectives. PUF, Paris.

European Commission. Integrated Territorial Investment, 2014. Online: http://ec.europa.eu/regional_policy/ sources/docgener/informat/ 2014/iti_en.pdf (accessed 12 June 2017).

Europe 2020. Strategy for intelligent and sustainable growth promoting social inclusion. Commission Communication, Brussels, 3.3.2010, $\operatorname{COM}(2010) 2020$ final. Online: www.ec.europa.eu/eu2020/pdf/1_PL_ACT_part1_ v1.pdf. (accessed 26 May 2017)

Frankowski J., Szmytkowska M., 2015. Regionalne zróżnicowanie nowych partnerstw miejskich w Polsce. (Regional diversity of new urban partnerships in Poland). Zarzadzanie Publiczne 2(30): 131-152.

Gorzelak G., 2014. Wykorzystanie środków Unii Europejskiej dla rozwoju kraju - wstępne analizy (Application of European Union funds for country development - preliminary analysis). Studia Regionalne i Lokalne 3(57): 5-25.

Hamilton D.K., 2000. Organizing government structure and governance functions in metropolitan areas in response to growth and change: A critical overview. Journal of $U$ rban Affairs 22(1): 65-84.

Heffner K., Gibas P., 2013. Obszary funkcjonalne ośrodków regionalnych $\mathrm{w}$ Polsce (Functional areas of regional centres in Poland). In: Nowakowska A. (ed.), Zrozumieć terytorium. Idea i praktyka. Wydawnictwo Uniwersytetu Łódzkiego, Łódź: 217-240.

Heinelt H., Kübler D. (eds), 2005. Metropolitan governance. Capacity, democracy and the dynamics of place. Routledge, London.

Heinelt H., Razin E., Zimmermann K. (eds), 2011. Metropolitan governance. Different paths in contrasting contexts: Germany and Israel. Campus Verlag, Frankfurt, New York.

Herbst K., Wójcik P., 2013. Delimitacja dyfuzji rozwoju z miast metropolitalnych $\mathrm{z}$ wykorzystaniem korelacji przestrzennej (Delimitation of diffusion of development from metropolitan cities using spatial correlation) Studia Regionalne i Lokalne 4(54): 5-21.

Herrschel T., Newman P., 2002. Governance of Europe's city regions. Planning, policy and politics. Routledge, London.

Hulst R., van Montfort A., 2007. Inter-municipal cooperation in Europe. Springer, Dordrecht.

Izdebski H., 2010. Dwadzieścia lat samorządu terytorialnego - potrzeba rozwiązania problemu metropolii (Twenty years of local self-government - the need to solve the problem of the metropolis). In: Lutrzykowski R., Gawłowski R. (eds), Metropolie. Wyzwanie polskiej polityki miejskiej. Wydawnictwo Adam Marszałek, Torun.

Janas K., Jarczewski W. (eds), 2016. Raport o stanie polskich miast. Zarzadzanie obszarami miejskimi (Report on the state of Polish cities. The management of urban areas). Obserwatorium Polityki Miejskiej Instytutu Rozwoju Miast, Kraków.

Jouve B., Lefevre C. (eds), 2002. Local power, territory and institutions in European metropolitan regions. Frank Cass, London.
Koncepcja Przestrzennego Zagospodarowania Kraju 2030 (National Spatial Development Concept 2030), 2011. Ministry of Regional Development, Warsaw.

Kaczmarek T., Mikuła Ł., 2007. Ustroje terytorialno-administracyjne obszarów metropolitalnych w Europie (Territorial and administrative organisation of metropolitan areas in Europe). Bogucki Wydawnictwo Naukowe, Poznań.

Kaczmarek T., 2015. Functional urban areas as the focus of development policy in Poland. Rozwój Regionalny i Polityka Regionalna 29: 9-20.

Kaczmarek T., Ryder A., 2015. Top-down and bottom-up metropolitan integration in Poland. In: Buček J., Ryder A. (eds), Governance in Transition. Springer Science+Business Media B.V., Dordrecht: 19-40.

Knieling J., 2011, Metropolitan networking in the western Baltic Sea region: Metropolitan region Hamburg between multilevel governance and soft spatial development. In: Herrschel T., Tallberg P. (eds), The Role of Regions? Networks, Scale, Territory. Kristianstads Boktryckeri, Stockholm: 195-214.

Kociuba D., 2017. Zintegrowane Inwestycje Terytorialne jako narzędzie zarządzania terytorialnego w miejskich obszarach funkcjonalnych (Integrated Territorial Investments as a tool of territorial governance in functional urban areas). Studia KPZK PAN 174: 144-153.

Kociuba D., 2017a. Delimitacja miejskich obszarów funkcjonalnych ośrodków wojewódzkich $\mathrm{w}$ realizacji Zintegrowanych Inwestycji Terytorialnych w Polsce - teoria versus praktyka (Delimitation of functional urban areas of voivodeship centres in Poland - Theory vs. practice). Studia Regionalne i Lokalne 3(69): 54-78.

Kozak M., 2015. Podsumowanie cyklu spotkań ws. ZIT: wnioski i rekomendacje dotyczace Strategii ZIT (Summary of the ITI cycle of meetings: Conclusions and recommendations on the ITI Strategy). Prezentacja z warsztatów dotyczących wdrażania ZIT w Polsce. Zakopane 20.01.2015.

Kurowska J., Lackowska M., 2016. Metropolitalne kolory europeizacji. Instytucjonalizacja współpracy w funkcjonalnych obszarach miejskich w Polsce w świetle nowych instrumentów polityki spójności UE (Metropolitan colours of europeanisation. Institutionalisation of cooperation in functional urban areas in Poland in the context of new EU Cohesion Policy instruments). Studia Regionalne i Lokalne 1(63): 82-107.

Leipzig Charter on Sustainable European Cities, 2007.

Markowski T., 2011. Dylematy terytorialnego wymiaru w krajowych i regionalnych dokumentach strategicznych (Dilemmas of territorial dimension in national and regional strategic documents). Studia KPZK PAN 137: 7596.

Markowski T., 2013. Territorial dimension of integrated development policy - Expectations and challenges concerning planning and institutional systems. Studia Regionalia 35: 51-64.

McCann P., Ortega-Argilés R., 2013. Some practical elements associated with the design of an integrated and territorial place-based approach to EU Cohesion policy. In: Crescenzi R., Perocco M. (eds), Geography, Institutions and Regional Economic Performance. Springer, New York: 95-118.

National Strategy of Regional Development 2010-2020 - regions, cities and rural areas (Krajowa Strategia Rozwoju Regionalnego 2010-2020 - regiony, miasta i obszary wiejskie), 2010. Ministry of Regional Development, Warsaw 
National Urban Policy 2023 (Krajowa Polityka Miejska 2023), 2015. Ministry of Infrastructure and Development, Warsaw.

Noworól A., 2014. Territorial partnerships as an instrument of urban policy. Biuletyn KPZK 253: 11-28.

OECD 2001. Territorial Outlook. Paris.

OECD 2009. Regions matter: Economic recovery, innovation and sustainable growth.

OECD 2011. Urban Policy Reviews, Poland. OECD iLibrary.

Pietrzyk I., 2004. Polityka regionalna UE $i$ regiony w państwach członkowskich (EU regional policy and regions in the Member States). Wydawnictwo Naukowe PWN, Warszawa.

Porawski A. (ed.), 2013. Wspótpraca jednostek samorządu terytorialnego w Polsce. Stan i potrzeby (Cooperation of local government units in Poland. State and prospects). Związek Miast Polskich, Poznań.

Priebs A., 2010. Entwicklung, Stand und Perspektiven stadtregionale Planungs- und Verwaltungsinstitutionen in Deutschland. Öffentliche Verwaltung 63: 503-515.

Principles of accommodating the urban dimension of the EU's Cohesion Policy, including Integrated Territorial Investments (Zasady uwzględniania wymiaru miejskiego polityki spójności UE, w tym realizacja Zintegrowanych Inwestycji Terytorialnych) 2013. Ministry of Regional Development, Warsaw.

Regulation (EU) of the European Parliament and of the Council No. 1301/2013 of 17 December 2013 on the European Regional Development Fund and the specific provisions concerning the Investment for growth and jobs goal and repealing Regulation (EC) No. 1080/2006.

Regulation (EU) of the European Parliament and of the Council No. 1304/2013 of 17 December 2013 on the European Social Fund and repealing of Council Regulation (EC) No. 1081/2006.

Regulation (EU) of the European Parliament and of the Council No. 1303/2013 of 17 December 2013 laying down common provisions on the European Regional Development Fund, the European Social Fund, the Cohesion Fund, the European Agricultural Fund for Rural Development and the European Maritime and Fisheries Fund and repeal Council Regulation (EC) No. 1083/2006.
Rodríguez-Pose A., Fratesi U., 2002. Between development and social policies: The impact of European Structural Funds in Objective 1 regions. Regional Studies 38(1): 97113.

Salet W., Thornley A., Kreukels A., 2003. Metropolitan governance and spatial planning. Comparative case studies of European city-regions. Spon Press, London.

Sellers J., Hoffmann-Martinot V., 2008. Metropolitan governance. Decentralization and Local Democracy in the World: 255-279.

Strategy for the Integrated Territorial Investments of the Lublin Functional Area in the years 2014-2020 (Strategia Zintegrowanych Inwestycji Terytorialnych Lubelskiego Obszaru Funkcjonalnego na lata 2014-2020) 2016. Lublin.

Szlachta J., Zaucha J., 2014. Wzmacnianie terytorialnego wymiaru polityki spójności $\mathrm{w}$ Polsce $\mathrm{w}$ latach 2014-2020 (Strengthening the territorial dimension of cohesion policy in Poland in the years 2014-2020). In: Klasik A., Kuźnik F. (eds), Miasta - metropolie - regiony. Nowe orientacje rozwojowe. WUE w Katowicach: 29-54.

Śleszyński P., 2013. Delimitacja miejskich obszarów funkcjonalnych stolic województw (Delimitation of the urban functional areas of voivodship capitals). Przeglad Geograficzny 85(2): 173-197.

Śleszyński P., 2014. Delimitation and typology of functional urban regions in Poland based on commuting. Geographia Polonica 87(2): 317-320.

Treaty of Lisbon amending the Treaty on European Union and the Treaty establishing the European Community. Brussels, 3 December 2007, adopted 2009. Online: http://www.consilium.europa.eu/uedocs/cmsUpload/cg00014.en07.pdf (accessed 25 May 2017)

Umowa Partnerstwa (Partnership Agreement) 2014. Ministry of Infrastructure and Development, Warsaw.

Urban Agenda for the EU 'Pact of Amsterdam' Agreed at the Informal Meeting of EU Ministers Responsible for Urban Matters on 30 May 2016 in Amsterdam, The Netherlands. Online: http://www.eukn.eu/fileadmin/Files/EUKN_ Documents/05_Paper_1_.pdf (accessed 23 May 2017)

White Book for the Metropolitan Areas (Biała Księga Obszarów Metropolitalnych) 2013. Ministry of Administration and Digitization, Warszawa. 